\title{
Chemical variability in Amazonian palm fruits: açaí (Euterpe oleracea Mart.), buriti (Mauritia flexuosa L. f.), and inajá [Maximiliana maripa (Aubl.) Drude] (Arecaceae)
} Variabilidade química em frutos de palmeiras amazônicas: açaí (Euterpe oleracea Mart.), buriti (Mauritia flexuosa L. f.) e inajá [Maximiliana maripa (Aubl.) Drude] (Arecaceae)

\author{
Magda Márcia Becker', Vinicyus Teles Chagas', Jean-Louis Marty", \\ Teresa Maria Fernandes de Freitas Mendes'II', Gilvanda Silva Nunes' \\ 'Universidade Federal do Maranhão. São Luís, Maranhão, Brasil \\ "Université de Perpignan Via Domitia. Perpignan, França \\ '"'Universidade Federal de Roraima. Boa Vista, Roraima, Brasil
}

\begin{abstract}
The bromatological composition, mineral content, bioactive compounds, and antioxidant capacity of three native Amazon Arecaceae fruits (buriti, açaí, and inajá) were chemically evaluated. These fruits showed high moisture contents $(>55 \%)$, and levels of ash values, total crude protein, and total carbohydrates in the range of $0.68-1.28 \%, 0.49-$ $2.14 \%$, and $6.10-26.51 \%$, respectively. High levels of total lipids were found in buriti (21.0\%). A wide range of mineral content was detected and the highest levels were found in the pulps of buriti ( $\mathrm{Ca}, \mathrm{Cu}, \mathrm{Fe}$, and $\mathrm{Mg}$ ), inajá ( $\mathrm{Na}$ and $\mathrm{Zn}$ ) and açaí (Mn). All three fruits showed antioxidant activity with important levels of phenolic compounds and good or rich content of vitamin C. This study provides new data on the antioxidant activity and the nutritional composition of native Amazonian fruits. Based on this study, these fruits are suitable for use in the food and cosmetics industries, as well as in pharmaceutical compositions.
\end{abstract}

Keywords: Native Amazonian fruits. Bromatological composition. Minerals. Antioxidant capacity.

Resumo: Foram quimicamente avaliados as composições bromatológicas, os teores minerais, os compostos bioativos e a capacidade antioxidante de três frutos de palmeiras (buriti, açaí e inajá), nativos de Amazônia. Os frutos mostraram elevados teores em umidade (> 55\%), níveis de cinzas, proteína bruta total e carboidratos totais na faixa de 0,68-1,28\%, 0,49-2,14\% e 6,10-26,51\%, respectivamente. Altos teores em lipídios foram obtidos na polpa de buriti (21,0\%). Uma ampla faixa de conteúdo mineral foi determinada, na qual os maiores teores estão nas amostras de buriti (Ca, Cu, Fe e Mg), na polpa de inajá ( $\mathrm{Na}$ e $\mathrm{Zn}$ ) e no açaí (Mn). Todos os frutos mostraram atividade antioxidante com níveis importantes de compostos fenólicos e boas ou ricas concentrações em vitamina C. Este estudo fornece novos dados sobre a atividade antioxidante e a composição nutricional de frutos nativos amazônicos. Com base neste trabalho, estes frutos são promissores para utilização nas indústrias de alimentos e de cosméticos, bem como em composições farmacêuticas.

Palavras-chave: Frutos nativos amazônicos. Composição bromatológica. Minerais. Capacidade antioxidante.

BECKER, M. M., V. T. CHAGAS, J.-L. MARTY, T. M. F. F. MENDES \& G. S. NUNES, 2018. Chemical variability in Amazonian palm fruits: açaí (Euterpe oleracea Mart.), buriti (Mauritia flexuosa L. f.), and inajá [Maximiliana maripa (Aubl.) Drude] (Arecaceae). Boletim do Museu Paraense Emílio Goeldi. Ciências Naturais 13(1): 67-77.

Autora para correspondência: Magda Márcia Becker. Universidade Federal do Maranhão. Programa em Biodiversidade e Biotecnologia Bionorte. Avenida Portuguesa, 1966 - Bacanga. São Luís, MA, Brasil. CEP 65080-805 (magda.becker@hotmail.com).

Recebido em 08/03/2017

Aprovado em 30/10/2017

Responsabilidade editorial: Fernando da Silva Carvalho Filho

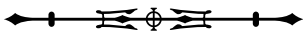




\section{INTRODUCTION}

Arecaceae, or the palm family (formerly Palmeae), is one of the largest botanical families of economic and ecological importance and among the first groups of plants that have gained significant attention regarding the risks of becoming endangered (Moore, 1979; Balick \& Beck, 1990; Zambrana et al., 2007). This family has a great diversity comprising 283 species in Brazil, where 147 species are native to the Amazon biome (Leitman et al., 2016).

In addition to the importance in the rainforest structure and food source for many animals and humans, the palm trees have great economic potential to ornamental plant, medicine and cosmetic industries for human (Henderson, 1995; Lorenzi et al., 2004) (Arasato et al., 2011, p. 7630).

Although some Arecaceae species, including some from Brazil, have been analyzed for centesimal composition in past years and a plethora of literature has reported on palm fruits (Silva et al., 2015; Crepaldi et al., 2000; Hiane et al., 2003; Menezes et al., 2008; Teixeira da Silva de La Salles et al., 2010; Coimbra \& Jorge, 2011), there is still a lack of research on the industrial applications of some palm trees.

Palms fruits comprise nutritionally important foods due their protective effect attributed to the presence of constituents such as minerals and high levels of phytochemicals with antioxidant properties (Nunes et al., 2011; Kahl et al., 2012; Liu, 2013; Kozlowska \& Szotask-Wegierek, 2014; Wang et al., 2013). Therefore, data on the composition of native fruits are essential to encourage national and international marketing; assist the food, cosmetics, bio-cosmetics and others industries; and support policies to protect the environment and biodiversity. Meanwhile, an adequate knowledge of the composition aids quality control and food safety, as well as the evaluation and adequacy of intake of individual nutrients to the population.

Açaí (Euterpe oleracea Mart.) is a typical Amazonian palm in Brazil. Its fruits are globular or lightly depressed drupes with a diameter around $1.5 \mathrm{~cm}$ and weighing $1.5 \mathrm{~g}$ on average. The pulp has an exotic flavor, as well as high antioxidant and anti-inflammatory properties that classified it as the new 'super fruits'. It is consumed pure or accompanied with manioc flour, fried fish, or shrimp, as well as being used yet in manufacturing of juices, ice cream, jams, jellies, açaí wine, and dyes. Açaí plays an important socioeconomic and cultural role since the fruits have a high regional consumption, and their export has increased greatly in recent years (Souza et al., 2011; Brasil, 2015).

Buriti (Mauritia flexuosa L. f.) is an Amazon palm tree with a height of 15 to $20 \mathrm{~m}$ and is typical of muddy riverbanks and river islands. Its fruit is subglobose to elliptical, varies from 4 to $5 \mathrm{~cm}$ in diameter, and are covered with reddish-brown scales. The pulp is orange colored, oleaginous, and tasty. Buriti fruit pulp is consumed in natura, as juices, and in ice cream. The unprocessed oil is used to fry foods, like fish. In popular medicine, the fruit is used, for example, as a cold remedy, in infant nutrition, and for vitamin A deficiencies (Carneiro \& Carneiro, 2011; Darnet et al., 2011).

Inajá fruits (Maximiliana maripa (Aubl.) Drude) are brown, oblong-ellipsoid, 4 to $5 \mathrm{~cm}$ long and 2.5 to $3 \mathrm{~cm}$ in diameter. The mesocarp has the fibrous outer layer, the inner layer being fleshy, with 0.3 to $0.5 \mathrm{~cm}$ in thickness and one to three seeds present (Shanley et al., 2010). The pulp of the fruit is consumed in natura or in the form of porridge and has been used in traditional medicine for the strengthening of debilitated people. However, it is not a highly appreciated fruit, possibly due to insufficient research and the consequent devaluation of the species (Villachica et al., 1996; Bezerra, 2011).

"Works related to the composition and quality of fruits and oils of native palm trees are important to add value to species still little explored in the region and consequently encourage the creation of new markets" (Santos et al., 2017, p. 2). The aim of this work is to perform bromatological analysis, mineral composition determination and antioxidant capacity analysis of buriti, inajá, and açaí pulps collected in the Amazonian biome, 
some of which have not been evaluated to date, in order to determine their potential use as foods and for other industrial purposes.

\section{MATERIALS AND METHODS}

\section{REAGENTS}

Analytical grade chemicals were employed in the preparation of all solutions. Deionised water (Milli-Q Millipore 18.2M $\Omega$ $\left.\mathrm{cm}^{-1}\right)$ was used in all experiments. All plastics and glassware were cleaned by soaking in dilute nitric acid (1:9). The standard solutions of analytes for calibration procedure were produced by diluting a stock solution of $1,000 \mathrm{mg} / \mathrm{L}$ of the investigated elements ( $\mathrm{Ca}, \mathrm{Cu}, \mathrm{Fe}, \mathrm{K}, \mathrm{Li}, \mathrm{Mg}, \mathrm{Mn}, \mathrm{Na}$, and Zn; from Merck Millipore Certipur ${ }^{\circledR}$, Specsol $\left.{ }^{\circledR}\right)$. The others reagents used were: nitro blue tetrazolium (NBT, N6876), hypoxanthine (HX, H9377), xanthine-oxidase enzyme (XOD from bovine milk, X4376), petroleum ether, phenolphthalein, sodium hydroxide $(\mathrm{NaOH})$, sulfuric acid $\left(\mathrm{H}_{2} \mathrm{SO}_{4}\right)$, potassium iodide $(\mathrm{KI})$, dry starch, potassium iodate $\left(\mathrm{KIO}_{3}\right)$, nitric acid $\left(\mathrm{HNO}_{3}\right)$, hydrogen peroxide $\left(\mathrm{H}_{2} \mathrm{O}_{2}\right)$, gallic acid, quecetin and oxide yttrium $\left(\mathrm{Y}_{2} \mathrm{O}_{3}\right)$, all purchased from Sigma-Aldrich Corp (Nasdaq-Sial, Darmstadt, Germany).

\section{SAMPLE COLLECTION}

Three Amazon palm fruits were collected and used in the present study: açai (Euterpe oleracea), buriti (Mauritia flexuosa), and inajá (Maximiliana maripa), at complete physiological maturity, were collected in Roraima state (02 47.177' N; 60 45.096' W; 3 22' 17.7" N; 59 51' $45.0^{\prime \prime} \mathrm{W} ; 02^{\circ} 46.579^{\prime} \mathrm{N} ; 60^{\circ} 42.285^{\prime} \mathrm{W}$, respectively). Fruit samples were refrigerated in the laboratory of the of Environmental Studies and Analysis Group (GEAA) at the Federal University of Maranhão, washed in deionized water and stored at $-20{ }^{\circ} \mathrm{C}$ until the time of analysis.

\section{BROMATOLOGICAL ANALYSIS}

Moisture content (MC), total ash (TA), hydrogen potential $(\mathrm{pH})$, acidity in citric acid (CA), crude protein (CP), and total lipids (TL) were performed according to the Association of Analytical Methods (AOAC methods) (Cunniff, 1998). Total carbohydrate (TC) was determined by the following equation: $[T C=100-(M C+T A+C P+T L)]$. Total energy value (TEV) was estimated as the at water conversion values of $4 \mathrm{kcal} / \mathrm{g}$ of protein and carbohydrates and $9 \mathrm{kcal} / \mathrm{g}$ of lipid, according to Merrill \& Watt (1973). All analyses were performed in triplicate.

\section{ANTIOXIDANTS}

\section{Antioxidant capacity}

The samples were washed, pulped and mixed in a stainless steel mixer. An amount of approximately $200 \mathrm{~g}$ of the pulp was filtered in vacuum Buchner funnel with qualitative filter paper, followed by a new filtration with a quantitative filter paper $(1.2 \mu \mathrm{m})$. A portion of $500 \mu \mathrm{L}$ of the obtained extract was diluted to $1 \mathrm{~mL}$ in $50 \mathrm{mM}$ Potassium Phosphate-Buffered Solution (K-PBS) containing $0.1 \mathrm{mM}$ ethylenediamine tetra-acetic acid (EDTA) (pH 7.5). From this solution, dilution was performed in decreasing concentrations in K-PBS ( $\mathrm{pH}$ 7.5).

A reaction mixture was prepared with $50 \mathrm{mMK}$ K-PBS (pH 7.5), $25 \mu \mathrm{M} \mathrm{HX}, 50 \mu \mathrm{M}$ NBT, the antioxidant fruit extract (distilled water for the blank) and $0.2 \mathrm{U} \cdot \mathrm{mL}^{-1} \mathrm{XOD}$, which was added last. The increase in absorbance for 15 min was recorded at $560 \mathrm{~nm}$ in a Beckman DU520 UV-Vis Spectrophotometer (Beckman Coulter France, S.A., Roissy CDG, France). Stock solutions of NBT, $H X$ and $X O D$ were prepared in K-PBS ( $\mathrm{pH}$ 7.5). All spectrometry assay measurements were performed in triplicate.

The method used was established by CortinaPuig et al. (2009), where the $\mathrm{O}_{2}{ }^{-}$radicals and uric acid were generated in vitro by the $H X X X O D$ system. The $\mathrm{O}_{2}{ }^{-}$- radicals reduce the NBT reagent (yellow color) into formazan (purple color), which is measured spectrophotometrically at $560 \mathrm{~nm}$. The presence of radical scavengers (the antioxidant sample) generates inhibition (competitive) in the formation of formazan 
leading to the decrease of its production rate and consequently of the absorbance.

The \% radical scavenging activity (RSA) of the plant extracts was calculated using the following formula:

RSA\% $=100 \times[$ (Abs. control - Abs. sample)/Abs. control $]$

Where: Abs. control is the absorbance of formazan without the sample; Abs. sample is the absorbance of formazan with the sample.

\section{Biocompounds}

\section{Determination of total phenols}

The total phenol content was determined by adopting the method of Pueyo \& Calvo (2009) and Berker et al. (2010). In buckets, we added $100 \mu \mathrm{L}$ of pulp etanolic extracts (1:1), $630 \mu \mathrm{L}$ deionized water, $20 \mu \mathrm{L}$ of $\mathrm{HCl}\left(1 \mathrm{~mol} \mathrm{~L}^{-1}\right)$ $150 \mu \mathrm{L} \mathrm{K} \mathrm{K}_{3} \mathrm{Fe}(\mathrm{CN})_{6}(1 \% \mathrm{~m} / \mathrm{v}), 50 \mu \mathrm{L}$ sodium dodecyl sulphate $(1 \% \mathrm{v} / \mathrm{v})$ and $50 \mu \mathrm{L} \mathrm{FeCl} \cdot 6 \mathrm{H}_{2} \mathrm{O}(0.2 \% \mathrm{~m} / \mathrm{v})$. The absorbance reading was done after 30 minutes at 750 nm using a Shimadzu UV-probe spectrophotometer. The calibration curve was obtained using standard solutions of gallic acid (1, 2, 4 and $\left.8 \mu \mathrm{g} \mathrm{mL}^{-1}\right)$. The results were expressed in equivalents of gallic acid in grams per $100 \mathrm{~g}$ of pulp (EGA $100 \mathrm{~g}^{-1}$ ).

\section{Determination of flavonoid content}

The concentration of flavonoids was determined by adapting the spectrophotometric procedure described in Chaillou et al. (2004) and Teles (2014). In buckets, we added $0.2 \mathrm{~mL}$ of metanolic pulp extracts (1:1), $0.2 \mathrm{~mL}$ methanolic solution of $\mathrm{AlCl}_{3}(5 \% \mathrm{~m} / \mathrm{v})$ and completed the volume to $2 \mathrm{~mL}$ with concentrated methanol. After 30 minutes, the absorbance was read at a wavelength of $425 \mathrm{~nm}$ using a Shimadzu UV-probe spectrophotometer. The calibration curve was obtained using standard solutions of quercetin. The results were expressed in equivalents of quercetin in milligrams per $100 \mathrm{~g}$ of pulp (EQE·100 $\left.\mathrm{g}^{-1}\right)$.

\section{Ascorbic acid}

The vitamin $C$ concentration was determined by redox titration using iodine solution. Masses of the homogenized sample guaranteeing a vitamin $\mathrm{C}$ content of more than $5 \mathrm{mg}$ were added, with $50 \mathrm{~mL}$ deionized water, $10 \mathrm{~mL}$ sulphuric acid 20\% (v/w), $1 \mathrm{~mL} \mathrm{KI} \mathrm{10 \%} \mathrm{(m/w)} \mathrm{and} 1 \mathrm{~mL}$ amido $1 \%(\mathrm{~m} / \mathrm{w})$. The iodine generated was titrated against $0.02 \mathrm{~mol} \cdot \mathrm{L}^{-1} \mathrm{KIO}_{3}$.

\section{MINERAL ELEMENTS}

\section{Digestion procedure}

A mixture of 0.2-0.5 g of homogenized dry samples, 5.0 $\mathrm{mL}$ of concentrated $\mathrm{HNO}_{3}, 2.0 \mathrm{~mL}$ of $30 \% \mathrm{H}_{2} \mathrm{O}_{2}(\mathrm{v} / \mathrm{v})$ with $0.5 \mathrm{ml}$ of yttrium (100 $\left.\mathrm{mg} \cdot \mathrm{L}^{-1}\right)$ as internal standard, was submitted to heating in a closed microwave oven (MARSX press 6.0), which utilizes high voltages and microwave radiation to accelerate the sample acid digestion. The digestion procedure was based on the AOAC method (Jorhem \& Engman, 2000), according the following steps: 3 minutes at $250 \mathrm{~W}, 5$ minutes at $630 \mathrm{~W}, 22$ minutes at $500 \mathrm{~W}$, and 15 minutes at $0 \mathrm{~W}$. The resulting solution was diluted with deionized water to $25.0 \mathrm{ml}$ in a volumetric flask before being analyzed by inductively coupled plasma optical emission spectrometer (ICP-OES). Blanks were prepared in each lot of samples. All analyses were performed in triplicate.

\section{ICP-OES operational conditions}

Concentrations of three macroelements ( $\mathrm{Ca}, \mathrm{Mg}$, and $\mathrm{Na}$ ) and four microelements ( $\mathrm{Fe}, \mathrm{Mn}, \mathrm{Zn}$, and $\mathrm{Cu}$ ) were determined for the selected fruits. The measurements for simultaneous determination were carried out with an ICP-OES (Shimadzu, model 9820), equipped with a concentric nebulizer and allowing choice of the minitorch configuration between the radial or the axial mode in an integrated unit. Yttrium was used as an internal standard at a concentration of $2 \mathrm{mg} \cdot \mathrm{L}^{-1}$. Operating conditions are summarized in Table 1. 
Table 1. Operating conditions of the ICP-OES method used during elemental analysis of the selected Amazon palm fruits.

\begin{tabular}{|c|c|}
\hline Parameter & Value \\
\hline Radio frequency power & $1.2 \mathrm{~kW}$ \\
\hline Plasma argon flow rate & 10 L.min ${ }^{-1}$ \\
\hline Auxiliary argon flow rate & 0.6 L.min ${ }^{-1}$ \\
\hline Carrier gas & 0.7 L. $\min ^{-1}$ \\
\hline Exposure time & $30 s$ \\
\hline Solvent rinse time & $30 \mathrm{~s}$ \\
\hline Peristaltic pump rotation speed & $20-60$ rpm \\
\hline View direction & $\begin{array}{l}\text { Radial for } \mathrm{Mg} \text { and } \mathrm{Na} \text {; axial for } \\
\mathrm{Ca}, \mathrm{Cu}, \mathrm{Fe}, \mathrm{Mn} \text { and } \mathrm{Zn}\end{array}$ \\
\hline Nebulizer & Concentric \\
\hline Emission lines $(\lambda \mathrm{nm})$ & $\begin{array}{l}\mathrm{Ca}(183.801) ; \mathrm{Cu}(327.396) ; \\
\mathrm{Fe}(259.940) ; \mathrm{Mg}(383.826) ; \\
\mathrm{Mn}(257.610) ; \mathrm{Na}(589.592) ; \\
\mathrm{Zn}(213.856)\end{array}$ \\
\hline
\end{tabular}

\section{Figures of merit}

Calibration curves, linear working range over a wide range of analyte concentrations, multi-elemental response and method sensitivity were determined. The analytical performance of the method was evaluated considering the following figures of merit: practical linear range; precision and accuracy, sensitivity, estimated by limits of detection and quantification (LOD and LOQ, respectively); accuracy of the complete analysis by ICP-OES, since the digestion step to the spectrometric analysis itself, was estimated by the recovery indexes obtained by buriti sample fortification with two concentrations.

\section{RESULTS AND DISCUSSION}

\section{BROMATOLOGICAL ANALYSIS}

The results of proximate analyses for the three Arecaceae fruits studied are shown in Table 2. The açaí sample was prepared as a class B pulp $(12.84 \% \mathrm{~m} / \mathrm{v})$, as it is traditionally consumed and marketed.

The studied species had levels $M C$ ranging from 55.91 to $88.16 \%$, similar to reported values in the literature (Darnet et al., 2011; Manhães \& Sabaa-Srur, 2011; Nascimento et al., 2008; Bezerra et al., 2006). In the studied palm fruits, TA contents ranged from 0.68 to $1.28 \mathrm{~g} / 100 \mathrm{~g}$ in the pulps, and the buriti and inajá contents were statistically similar.

Buriti showed the highest TL and can be considered a rich natural sources of lipids (21.0\%), which corroborates with the use of this fruit in the food, pharmaceutical and cosmetics industries. The açaí and inajá pulps have similar oil content.

A comparison of lipid composition with data from the literature is complex, due to interrelated factors such as genetics, soil, climate, and stage of maturity of the plant and fruits, collection periods. Moreover, lipid accumulation in plants depends greatly on culture conditions such carbon source, nitrogen source, $\mathrm{C} / \mathrm{N}$ molar ratio, temperature, and oxygenation (Sestric, 2015; Ageitos et al., 2011).

Table 2. Proximal composition of the selected Amazon palm fruits (relative standard deviation - RSD). Legends: $M C=$ moisture content; $\mathrm{TA}=$ total ash; $\mathrm{TL}=$ total lipids; $\mathrm{CP}=$ crude protein; $\mathrm{TC}=$ total carbohydrate; $\mathrm{TEV}=$ total energy value; $\mathrm{CA}=$ acidity in citric acid. All results are presented together the respective RSD. $N=3$. Means followed by the same letter in the columns do not differ significantly from each other by the Tukey test at the $5 \%$ probability level.

\begin{tabular}{|c|c|c|c|c|c|c|c|c|}
\hline \multirow{3}{*}{$\begin{array}{l}\text { Amazon } \\
\text { fruits }\end{array}$} & & & & & & & \multirow{3}{*}{$\begin{array}{c}\text { TEV } \\
\left(\mathrm{kcal}^{1} 100 \mathrm{~g}^{-1}\right)\end{array}$} & \multirow{3}{*}{$\mathrm{pH}$} \\
\hline & $M C$ & TA & $T L$ & $\mathrm{CP}$ & $\mathrm{TC}$ & $C A$ & & \\
\hline & \multicolumn{6}{|c|}{$\left(g \cdot 100 g^{-1}\right)$} & & \\
\hline Açaí & $\begin{array}{l}88.16 \\
(1.89)\end{array}$ & $\begin{array}{c}0.68 \\
(10.51)\end{array}$ & $\begin{array}{c}4.33 \\
(0.35)^{\mathrm{a}}\end{array}$ & $\begin{array}{c}0.72 \\
(7.22)\end{array}$ & 6.10 & $\begin{array}{l}0.082 \\
(6.62)\end{array}$ & 66.27 & $\begin{array}{c}5.69 \\
(0.30)^{\mathrm{a}}\end{array}$ \\
\hline Buriti & $\begin{array}{l}55.91 \\
(0.32)\end{array}$ & $\begin{array}{c}1.28 \\
(1.24)^{\mathrm{a}}\end{array}$ & $\begin{array}{c}21.0 \\
(0.45)\end{array}$ & $\begin{array}{c}2.14 \\
(5.68)\end{array}$ & 19.67 & $\begin{array}{c}0.89 \\
(1.00)\end{array}$ & 276.27 & $\begin{array}{c}3.84 \\
(8.41)\end{array}$ \\
\hline Inajá & $\begin{array}{l}67.49 \\
(0.13)\end{array}$ & $\begin{array}{c}1.24 \\
(1.01)^{\mathrm{a}}\end{array}$ & $\begin{array}{c}4.27 \\
(8.63)^{\mathrm{a}}\end{array}$ & $\begin{array}{c}0.49 \\
(1.46)\end{array}$ & 26.51 & $\begin{array}{c}0.06 \\
(4.70)\end{array}$ & 146.46 & $\begin{array}{c}5.73 \\
(0.36)^{a}\end{array}$ \\
\hline
\end{tabular}

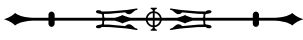


The obtained results, nevertheless, show some agreement with the literature for açaí and buriti pulps (Brasil, 2015; Darnet et al., 2011; Canuto et al., 2010; Aguiar, 1996).

The CP contents ranged from $0.49 \%$ in the inajá pulp to $2.14 \%$ in buriti. Therefore, the intake of $100 \mathrm{~g}$ of buriti pulp contributes approximately $8 \%$ of the recommended dietary allowances (RDA) of proteins to an adult man. The CP obtained from the inajá pulp was lower than those recorded by Mota \& França (2007), whereas for açaí (Yuyama et al., 2011) and buriti (Manhães \& SabaaSrur, 2011) our data presented a certain agreement with the literature.

The three species studied had TC ranging from 6.10 to $26.51 \mathrm{~g} 100 \mathrm{~g}^{-1}$. The proximate analysis of the TC content showed that inajá pulps are a major source of sugar.

Based on CP, TL and TC contents, the calorific values (TEV) of the fruits ranged from 66 to $276 \mathrm{kcal} 100 \mathrm{~g}^{-1}$. Only

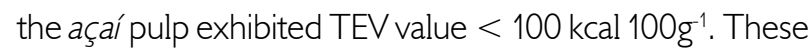
samples can be included in energy-restricted diets; on the other hand the buriti and inajá pulps presented high TEV and can be included in the high calorie diets.

For titratable acidity, among evaluated fruits, buriti showed a higher average value $(0.89 \%)$ and the lowest $\mathrm{pH}$ (3.89). The average acidity value obtained for buriti pulps was higher than that observed by Santos et al.
(2017) of $0.56 \%$, and for inajá (0.07\%) it was lower than their value (0.14). The $\mathrm{pH}$ values are statistically similar between açaí and inajá.

Data on food composition is extremely important for the development of food composition tables, consumption of balanced nutrients, assessment of the supply and food consumption of a country, verification of the nutritional adequacy of the diets of individuals and populations, evaluation of the nutritional status, and development of research regarding the relation between diet and disease, agricultural planning, and food industry inovation (Torres et al., 2000).

\section{MINERAL ELEMENTS}

Mineral concentrations in the palm fruits with their respective RSD, LOD, and LOQ, as well as the results of the addition tests, are presented in Table 3.

The results show that the method is precise with RSD $<10 \%$ for all samples and accurate with recuperation ranged from 88.54 to $109.50 \%$.

Plants are a source of minerals that are essential nutrients for the maintenance of human health. The RDA is a parameter used to stipulate the nutrient levels that meet the human needs of most healthy individuals. According to these parameters, the average daily requirements for adult males (19 to 30 years of age) of the evaluated minerals are

Table 3. Levels of mineral elements $\left(\mathrm{mg} \cdot 100 \mathrm{~g}^{-1}\right)$ in the selected Amazon fruits with respective RSD, LOD, and LOQ $\left(\mathrm{mg} \cdot \mathrm{L}^{-1}\right)$. All results are presented together the respective relative standard deviation (RSD). $N=3$. Means followed by the same letter in the columns do not differ significantly from each other by the Tukey test at probability level $p=0.05$.

\begin{tabular}{|c|c|c|c|c|c|c|c|}
\hline $\begin{array}{r}\text { Mineral } \\
\text { LOD } \\
\text { LOQ }\end{array}$ & $\begin{array}{c}\mathrm{Ca} \\
6.510^{-2} \\
2.42\end{array}$ & $\begin{array}{c}\mathrm{Na} \\
1.010^{-1} \\
3.49\end{array}$ & $\begin{array}{c}\mathrm{Mg} \\
2.010^{-3} \\
2.210^{-2}\end{array}$ & $\begin{array}{c}\mathrm{Cu} \\
4.010^{-4} \\
1.710^{-3}\end{array}$ & $\begin{array}{c}\mathrm{Fe} \\
5.010^{-4} \\
2.910^{-3}\end{array}$ & $\begin{array}{c}\mathrm{Mn} \\
7.1210^{-6} \\
1.210^{-5}\end{array}$ & $\begin{array}{c}Z n \\
3.010^{-4} \\
1.710^{-3}\end{array}$ \\
\hline & \multicolumn{6}{|c|}{ Concentration $\mathrm{mg} \cdot 100 \mathrm{~g}^{-1}(\mathrm{RSD})$} & \\
\hline Açaí & $61.47(6.17)$ & $4.05(3.41)^{\mathrm{a}}$ & $12.64(4.65)$ & $0.12(5.79)^{\mathrm{a} . \mathrm{b}}$ & $0.84(1.26)^{a}$ & $7.89(3.46)$ & $0.97(3.91)^{\mathrm{a}}$ \\
\hline Buriti & $107.12(1.55)$ & $2.97(5.92)^{\mathrm{a}}$ & $84.28(3.12)$ & $0.19(2.15)^{\mathrm{a}}$ & $0.94(1.91)^{\mathrm{a}}$ & $3.18(4.10)$ & $0.89(2.64)^{\mathrm{a}}$ \\
\hline Inajá & $19.82(7.74)$ & $4.21(5.87)^{\mathrm{a}}$ & $57.48(8.23)$ & $0.08(9.10)^{b}$ & $0.48(1.62)$ & $0.17(7.04)$ & $1.05(4.04)$ \\
\hline Addition Test & \multicolumn{6}{|c|}{ Recuperation \% (RSD) } & \\
\hline Buriti & $\begin{array}{l}107.08(9.90) \\
104.50(8.88)\end{array}$ & $\begin{array}{c}107.21(4.04) \\
100.9(1.29)\end{array}$ & $\begin{array}{l}108.33(1.63) \\
88.54(6.99)\end{array}$ & $\begin{array}{l}107.83(5.92) \\
102.90(2.10)\end{array}$ & $\begin{array}{l}97.00(8.02) \\
98.00(2.53)\end{array}$ & $\begin{array}{l}100.00(11.79) \\
100.00(0.00)\end{array}$ & $\begin{array}{c}109.50(7.43) \\
90.3(3.33)\end{array}$ \\
\hline
\end{tabular}


as follows: $\mathrm{Na}=1.3$ to $1.5 \mathrm{~g} /$ day; $\mathrm{Ca}=1 \mathrm{~g} /$ day; $\mathrm{Mg}=310$ to $400 \mathrm{mg} /$ day; $\mathrm{Cu}=0.9 \mathrm{mg} /$ day; $\mathrm{Fe}=8$ to $18 \mathrm{mg} /$ day; $M n=1.8$ to $2.3 \mathrm{mg} /$ day; $\mathrm{Zn}=8$ to $11 \mathrm{mg} /$ day (Institute of Medicine, 2006).

Ca presented the highest macromineral contents in the majority of the samples, followed by $\mathrm{Mg}$ and $\mathrm{Na}$. The highest micromineral contents were observed for $\mathrm{Mn}$ in açaí and buriti pulp, as well as Zn in inajá samples.

Ca plays a key role in the health of bones, and it is involved in vascular, neuromuscular, and glandular functions in the body (Institute of Medicine, 2006). Ca levels $<10.71 \%$ of the RDA were found in the fruits, and they may be introduced into the diet of populations with a Ca deficiency.

Good results are shown for $\mathrm{Na}$, because the $\mathrm{Na}$ concentrations showed values of the RDA $<0.32 \%$. In the human body, $\mathrm{Na}$ is necessary to maintain extracellular fluid volume and plasma osmolality, but there is little evidence of any adverse effect from low dietary sodium. On other hand, adverse effects of increased sodium intake are elevated blood pressure, which is directly related to cardiovascular disease and end-stage renal disease.

Concentrations of $\mathrm{Mg}$ ranged from 84.28 to 12.64 in the palm fruits, which show that buriti and inajá pulps are natural sources in this macromineral.

$\mathrm{Cu}$ concentrations ranged from 0.08 to 0.19 in the fruits. Buriti showed the highest content, being classified as a natural source of this micromineral because it encompasses $21.11 \%$ of the RDA. Therefore, buriti consumption can help to prevent diseases associated with $\mathrm{Cu}$ deficiency, including normocytic, hypochromic anemia, leucopenia, and neutropenia.

The highest content of Fe was founded in buriti samples, which provide $11.75 \%$ of the RDA for adult males.

The results showed highest levels of micronutrients for açaí, followed by buriti and inajá. Although of contribution of $\mathrm{Mn}$ was $>100 \%$ of RDA when açaí e buriti were ingested at $100 \mathrm{~g}$ per day, the concentrations are below the maximum tolerable intake level ( 11 mg.day ${ }^{1}$ ) and only a small percentage, 3 to $5 \%$, of dietary $\mathrm{Mn}$ is really absorbed by the body, while much absorbed $\mathrm{Mn}$ is excreted very rapidly into the gut via the bile and only a small amount is retained. In general, the palm fruits contain high contents of $\mathrm{Mn}$ and can contribute to prevent diseases related to Mn deficiency.

Inajá showed the highest content of $\mathrm{Zn}$ and could contribute with $13.13 \%$ of the RDA when $100 \mathrm{~g}$ of this fruit pulp are ingested daily.

\section{ANTIOXIDANT CAPACITY}

The results of the antioxidant activity expressed in function of the production rate of formazan for different title mass (\% m/v) of analyzed fruits, and standard deviations for each analysis are shown in Figure 1. Although acerola (Barbados cherry or West Indian cherry) is not an Amazonian fruit, this fruit was used for comparative purposes, due to its high ascorbic acid content and antioxidant potential (Nunes et al., 2011; Lima et al., 2011).

All the fruits were observed to show antioxidant activity. The inhibition of $\mathrm{O}_{2}{ }^{-}$radicals generated by the antioxidant action of the selected fruits were revealed by the smaller amount of NBT which was reduced to formazan when the reaction catalyzed by $X O D$ processed in presence of its diluted pulps. As expected, the superoxide radical scavenging activity (RSA) was higher for acerola (96.39\%), followed by buriti, açaí and inajá.

Values of RSA were: buriti (84.28\%), açaí (84.21\%) and inajá (73.60\%). Evaluating the closeness of the obtained results, a one-way ANOVA test was applied, followed by Tukey's test, in order to identify significant differences among averages obtained with 20\% of the fruits dilution. The ANOVA and Tukey's test showed buriti and açaí with no significant difference $(p<0.05)$ between them in relation to their antioxidant behavior.

Concentrations of vitamin C, phenolic compounds, and flavonoids in the fruits studied are presented in Table 4 , as well as their antioxidant capacity for comparative purposes. 


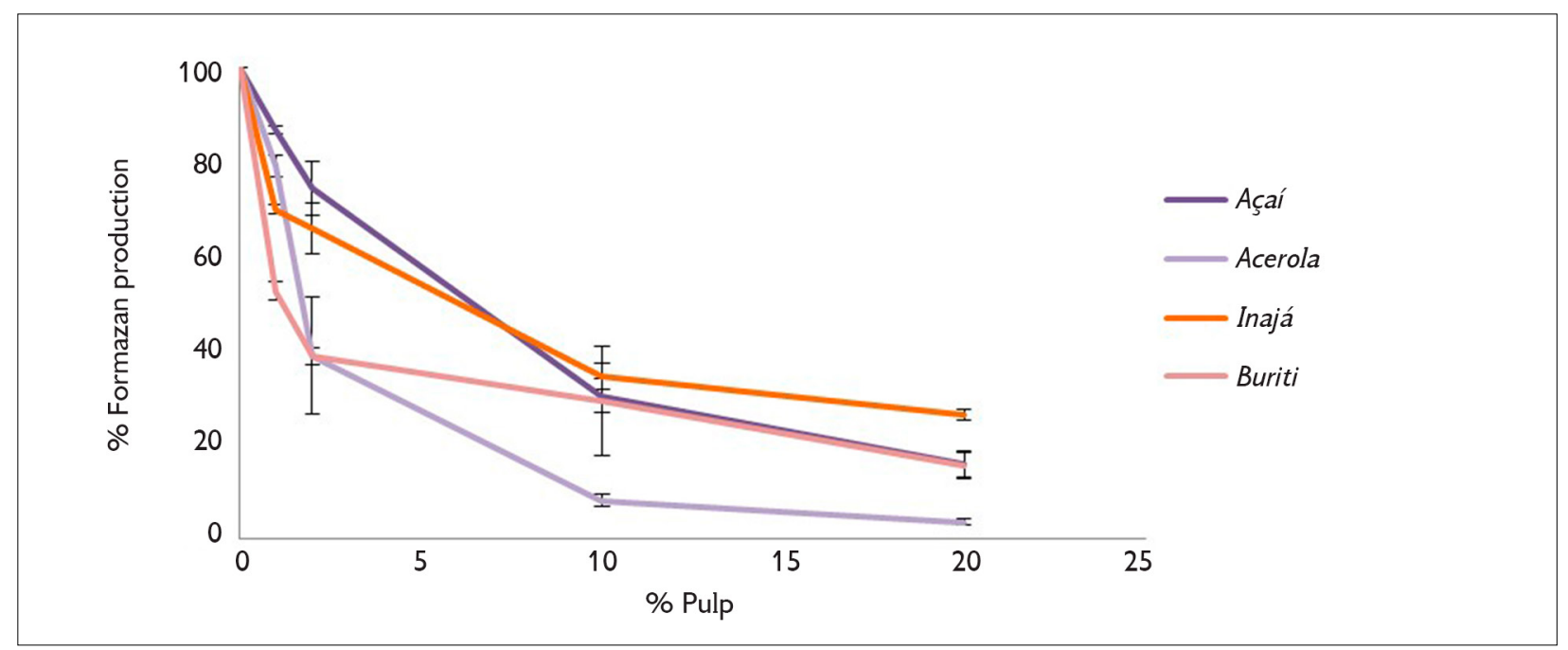

Figure 1. Antioxidant activity expressed as a function of production rate of Formazan for different title mass (\%, m/v).

Table 4. Concentrations of vitamin C, phenolic compounds and flavonoids in wet mass, and antioxidant capacity observed for fruit extract at $20 \%(\mathrm{~m} / \mathrm{v})$. Legend: ND = undetectable signal. Means followed by the same letter in the columns do not differ significantly from each other by the Tukey test at $5 \%$ probability level

\begin{tabular}{c|c|c|c|c}
\hline $\begin{array}{r}\text { Bioactive } \\
\text { compounds }\end{array}$ & $\begin{array}{c}\text { Vitamin C } \\
\mathrm{mg} \cdot 100 \mathrm{~g}^{-1}\end{array}$ & $\begin{array}{c}\text { Phenolic compounds } \\
\text { EAG·100g }\end{array}$ & $\begin{array}{c}\text { Flavonoids } \\
\text { EQE·100 g-1 }\end{array}$ & $\begin{array}{c}\text { Antioxidant } \\
\text { capacity (RSA \%) }\end{array}$ \\
\hline Açaí & $80,00 \pm 7,07$ & $4,86 \pm 0,79^{\mathrm{a}}$ & $10,21 \pm 1,16$ & $84,21 \pm 2,55^{\mathrm{a}}$ \\
\hline Buriti & $21,87 \pm 1,63$ & $5,17 \pm 1,60^{\mathrm{a}}$ & $\mathrm{ND}$ & $84,28 \pm 2,90^{\mathrm{a}}$ \\
\hline Inajá & $37,70 \pm 1,39$ & $3,61 \pm 0,40^{\mathrm{a}}$ & $\mathrm{ND}$ & $73,60 \pm 1,08$ \\
\hline
\end{tabular}

The values of vitamin $\mathrm{C}$ content in fresh fruits are in the range of 21.87 to $80.0 \mathrm{mg} \cdot 100 \mathrm{~g}^{-1}$ for buriti and açaí pulp, respectively. The Institute of Medicine (2006) establishes the RDA of $90 \mathrm{mg}$ of vitamin C for a healthy adult, which allows classifying açaí and inajá pulps as foods high in vitamin $C$ and buriti as a source in this nutrient. Comparing the obtained results with data from the literature, it can be seen that the vitamin $C$ contents obtained are within the range reported for açaí pulp (Rufino et al., 2010) and buriti (Gonçalves, 2008). There were no published records for vitamin $C$ concentrations in inajá pulp, and therefore, this work is the first to present data on the ascorbic acid content in this fruit.

There are no significant difference $(p<0.05)$ between the phenolic compound concentrations of the palm fruits. The knowledge of the content of phenolic compounds in fruits is important because it reflects the mechanism of adaptation and resistance of the plant to the environment, and it influences the flavor and the technological characteristics of the food, as well as the nutritive and functional potential of these fruits (Rocha et al., 2013).

Comparing the results of the phenolic compound content with the literature, lower values were observed than those reported by Yamaguchi (2015) for extracts of hydroalcoholic residues of açaí fruits, while the present results were higher for açaí (Rufino et al., 2010) and buriti (Manhães \& Sabaa-Srur, 2011).

Only açaí pulp showed quantifiable concentrations of flavonoids. 


\section{CONCLUSIONS}

Although the three tested fruits belong to the same botanical family, their analyses confirmed the natural compositional variability of these plants, which may be related to the different genera to which they belong, as well as the edaphoclimatic conditions of their natural environments.

The fruits showed expected variations in bromatological parameters. They had good mineral contents, each being rich in one or more nutrients. From the nutritional point of view, their consumption can be recommended because of the beneficial effects of adequate contents, such as moisture, ash, lipid, protein, carbohydrate, and energy, as well as considerable mineral content, especially of microelements.

The chemical composition of inajá fruit is presented for the first time, and its nutritional potential revealed.

All the studied fruits may be considered promising sources of bioactive compounds having high antioxidant properties, increasing interest in them by the food industry because they retard oxidative degradation of lipids and thereby improve the quality and nutritional value of foods. Besides that, the fruits exhibit great potential for applications in the pharmaceutical, cosmetic, and food industries.

\section{ACKNOWLEDGEMENTS}

This work was supported by the Fundação de Amparo ao Desenvolvimento Científico e Tecnológico do Maranhão (FAPEMA) (Contract. 37906/2016).

\section{REFERENCES}

AGEITOS, J. M., J. A. VALLEJO, P. VEIGA-CRESPO \& T. G. VILLA, 2011. Oily yeasts as oleaginous cell factories. Applied Microbiology and Biotechnology 90(4): 1219-1227. DOI: <https://doi. org/10.1007/s00253-011-3200-z>.

AGUIAR, J. P. L., 1996. Table of nutrient composition of Amazonian foods. Acta Amazonica 26(1-2): 121-126. DOI: <https://doi. org/10.1590/1809-43921996261126>.

ARASATO, L. S., S. AMARAL \& C. D. RENNÓ, 2011. Detecting individual palm trees (Arecaceae family) in the Amazon rainforest using high resolution image classification. Anais do Simpósio Brasileiro de Sensoriamento Remoto 15: 7628-7635.
BALICK, M. J. \& H. T. BECK, 1990. Useful palms of the world: a synoptic bibliography. Columbia University Press, New York.

BERKER, K. I., K. GÜÇLÜ, İ. TOR, B. DEMIRATA \& R. APAK, 2010. Total antioxidant capacity assay using optimized ferricyanide/ prussian blue method. Food Analytical Methods 3(3): 154-168. DOI: <https://doi.org/10.1007/s12161-009-9117-9>.

BEZERRA, V. S., 2011. O inajá (Maximiliana maripa (Aubl.) Drude) como fonte alimentar e oleaginosa. Comunicado Técnico (EMBRAPA) 129: 1-6.

BEZERRA, V. S., L. A. M. FERREIRA, S. S. C. PEREIRA \& M. J. V. CARIM, 2006. O inajá (Maximiliana maripa (Aubl,) Drude) como potencial alimento e oleaginoso. Anais do Congresso Brasileiro de Plantas Oleaginosas, Óleos, Gorduras e Biodiesel 3: 301-305.

BRASIL, 2015. Alimentos regionais brasileiros: 2. ed. Ministério da Saúde, Brasília.

CANuto, G. A. B., A. A. O. XAVIER, L. C. NEVES \& M. T. BENASSI, 2010. Physical and chemical characterization of fruit pulps from Amazonia and their correlation to free radical scavenger activity. Revista Brasileira de Fruticultura 32(4): 1196-1205. DOI: <http://dx.doi.org/10.1590/S0100-29452010005000122>.

CARNEIRO, T. B. \& J. G. M. CARNEIRO, 2011. Frutos e polpa desidratada de buriti (Mauritia flexuosa L.): aspectos físicos, químicos e tecnológicos. Revista Verde 6(2): 105-111.

CHAILLOU, L. L., H. A. HERRERA \& J. F. MAIDANA, 2004. Estudio del propoleos de Santiago del Estero, Argentina. Food Science and Technology 24(1): 11-15. DOI: <http://dx.doi.org/10.1590/ S0101-20612004000100003>.

COIMBRA, M. C. \& N. JORGE, 2001. Proximate composition of guariroba (Syagrus oleracea), jerivá (Syagrus romanzoffiana) and macaúba (Acrocomia aculeata) palm fruits. Food Research International 44(7): 2139-2142. DOI: < https://doi.org/10.1016/j. foodres.2011.03.032>.

CORTINA-PUIG, M., X. MUÑOZ-BERBEL, R. ROUILLON, C. CALAS-BLANCHARD \& J. L. MARTY, 2009. Development of a cytochrome c-based screen-printed biosensor for the determination of the antioxidant capacity of orange juices. Bioelectrochemistry 76(1-2): 76-80. DOI: <https://doi. org/10.1016/j.bioelechem.2009.04.004>

CREPALDI, I. C., L. B. ALMEIDA-MURADIAN, M. D. G. RIOS \& M. V. C. PENTEADO, 2000. Composição nutricional do fruto do licuri (Syagrus coronata (Martius) Beccari). Revista Brasileira de Botânica 24(2): 155-159. DOI: <http://dx.doi.org/10.1590/ S0100-84042001000200004>.

CUNNIFF. P. A. (Ed.), 1998. Official methods of analysis of AOAC International: 16. ed. Association of Official Analytical Chemists, Arlington. 
DARNET, S. H., L. H. M. SILVA, A. M. C. RODRIGUES \& R. T. LINS, 2011. Nutritional composition, fatty acid and tocopherol contents of buriti (Mauritia flexuosa) and patawa (Oenocarpus bataua) fruit pulp from the Amazon region. Ciência e Tecnologia de Alimentos 31(2): 488-491.

GONÇALVES, A. E. S. S., 2008. Avaliação da capacidade antioxidante de frutas e polpa de frutas nativas e determinação dos teores de flavonóides e vitamina C. Dissertação (Mestrado em Ciência de Alimentos) - Universidade de São Paulo, São Paulo.

HENDERSON, A., 1995. The palms of the Amazon: 1-362. Oxford University Press, New York.

HIANE, P. A., D. BOGO, M. I. L. RAMOS \& M. M. RAMOS-FILHO, 2003. Carotenóides pró-vitamínicos a e composição em ácidos graxos do fruto e da farinha do babaçu (Scheelea phalerata Mart.). Ciência e Tecnologia de Alimentos 23(2): 206-209. DOI: <http:// dx.doi.org/10.1590/S0101-20612003000200018>.

INSTITUTE OF MEDICINE, 2006. Dietary reference intakes: the essential guide to nutrient requirements. National Academy Press, Washington. DOI: <https://doi.org/10.17226/11537>.

JORHEM, L. \&J. ENGMAN, 2000. Determination of lead, cadmium, zinc, copper, and iron in foods by atomic absorption spectrometry after microwave digestion: NMKL Collaborative Study. Journal of AOAC International 83(5): 1189-1203.

KAHL, V. F. S., J. M. REYES, M. S. SARMENTO \& J. SILVA, 2012. Mitigation by vitamin $C$ of the genotoxic effects of nicotine in mice, assessed by comet assay and micronucleus induction. Mutation Research 744(2): 140-144. DOI: <http://dx.doi.org/10.1016/j. mrgentox.2012.01.008>.

KOZLOWSKA, A. \& D. SZOTASK-WEGIEREK, 2014. Flavonoids: food source and health benefits. Roczniki Panstwowego Zakladu Higieny 65(2): 79-85.

LEITMAN, P., A. HENDERSON, L. NOBLICK, R. C. MARTINS \& K. SOARES, 2016. Arecaceae. In: JARDIM BOTÂNICO DO RIO DE JANEIRO (JBRJ). Lista de espécies da flora do Brasil. JBRJ, Rio de Janeiro. Available at: <http://floradobrasil.jbrj.gov.br/jabot/ FichaPublicaTaxonUC/FichaPublicaTaxonUC.do?id=FB34066>. Access on: January 5, 2017.

LIMA, V. L. A. G., E. A. MELO, I. O. PINHEIRO \& N. B. GUERRA, 2011. Antioxidant capacity of anthocyanins from acerola genotypes. Ciência e Tecnologia de Alimentos 31(1): 86-92. DOI: <http:// dx.doi.org/10.1590/S0101-20612011000100011>.

LIU, R. H., 2013. Health-promoting components of fruits and vegetables in the diet. Advances in Nutrition 4(3): 384S-392S. DOI: <http://dx.doi.org/10.3945/an.112.003517>.

LORENZI, H., H. M. SOUZA, J. T. MEDEIROS-COSTA, L. S. C. CERQUEIRA \& E. FERREIRA, 2004. Palmeiras brasileiras e exóticas cultivadas: 1-416. Plantarum, Nova Odessa.
MANHÃES, L. R. T. \& A. U. O. SABAA-SRUR, 2011. Centesimal composition and bioactive compounds in fruits of buriti collected in Pará. Food Science and Technology 31(4): 856-863. DOI: <http:// dx.doi.org/10.1590/S0101-20612011000400005>.

MENEZES, E. M. S., A. T. TORRES \& A. U. S. SRUR, 2008. Valor nutricional da polpa de açaí (Euterpe oleracea Mart.) liofilizada. Acta Amazonica 38(2): 311-316. DOI: <http://dx.doi.org/10.1590/ S0044-59672008000200014>.

MERRILL, A. L. \& B. K. WATT, 1973. Energy value of foods: basis and derivation. ARS United States Department of Agriculture (Agriculture Handbook, 74), Washington.

MOORE, H. E., 1979. Endangerment at the specific and generic level in palms. Principes 23(2): 47-64.

MOTA, R. V. \& L. F. FRANÇA, 2007. Estudo das características da ucuuba (Virola surinamensis) e do inajá (Maximiliana regia) com vistas à produção de biodiesel. Revista Científica da UFPA 6(1): $1-9$

NASCIMENTO, R. J. S., S. COURI, R. ANTONIASSI \& S. P. FREITAS, 2008. Composição em ácidos graxos do óleo da polpa de açaí extraído com enzimas e com hexano. Revista Brasileira de Fruticultura 30(2): 498-502. DOI: < http://dx.doi.org/10.1590/ S0100-29452008000200040>

NUNES, R. S., V. F. KAHL, M. S. SARMENTO, M. F. RICHTER, L. V. COSTA-LOTUFO, F. A. RODRIGUES, J. A. ABIN-CARRIQUIRY, M. M. MARTINEZ, S. FERRONATTO, A. B. FERRAZ \& J. DA SILVA, 2011. Antigenotoxicity and antioxidant activity of acerola fruit (Malpighia glabra L.) at two stages of ripeness. Plant Foods for Human Nutrition 66(2): 129-135. DOI: < https://doi.org/10.1007/ s11130-011-0223-7>

PUEYO, I. U. \& M. I. CALVO, 2009. Assay conditions and validation of a new $\cup V$ spectrophotometric method using microplates for the determination of polyphenol content. Fitoterapia 80(8): 465-467. DOI: <https://doi.org/10.1016/j.fitote.2009.06.008>.

ROCHA, M. S., R. W. FIGUEIREDO, M. A. M. ARAÚJO \& R. S. R. MOREIRA-ARAÚJO, 2013. Caracterização físico-química e atividade antioxidante (in vitro) de frutos do cerrado piauiense. Revista Brasileira de Fruticultura 35(4): 933-941. DOI: < http:// dx.doi.org/10.1590/S0100-29452013000400003>.

RUFINO, M. S., R. E. ALVES, E. S. BRITO, J. PÉREZ-JIMÉNEZ, F. SAURA-CALIXTO \& J. MANCINI-FILHO, 2010. Bioactive compounds and antioxidant capacities of 18 non-traditional tropical fruits from Brazil. Food Chemistry 121(4): 996-1002. DOI: <https://doi.org/10.1016/j.foodchem.2010.01.037>.

SANTOS, M. F. G., R. E. ALVES, E. S. BRITO, S. M. SILVE \& M. R. S. SILVEIRA, 2017. Quality characteristis of fruits and oils of palms native to the Brazilian Amazon. Revista Brasileira de Fruticultura 39: 1-6. DOI: <http://dx.doi.org/10.1590/010029452017305>. 
SESTRIC, R., 2015. Investigations of Single Cell Oils (SCO): an analysis of growth and lipid biosynthesis in oleaginous microbes for biodiesel production. Thesis (PhD in PHILOSOPHY) - University of Manitoba, Winnipeg.

SHANLEY, P., M. SERRA \& G. MEDINA (Ed.), 2010. Frutíferas e plantas úteis na vida amazônica. CIFOR/EMBRAPA Amazônia Oriental/IMAZON, Belém.

SILVA, R. B., E. V. SILVA-JUNIOR, L. C. RODRIGUES, L. H. C. ANDRADE, S. I. DA SILVA, W. HARAND \& A. F. M. OLIVEIRA, 2015. A comparative study of nutritional composition and potential use of some underutilized tropical fruits of Arecaceae. Anais da Academia Brasileira de Ciências 87(3): 1701-1709. DOI: < http:// dx.doi.org/10.1590/0001-3765201520140166>.

SOUZA, M. O., R. C. SANTOS, M. E. SILVA \& M. L. PEDROSA, 2011. Açaí (Euterpe oleraceae Martius): chemical composition and bioactivity. Jounal of the Brazilian Society for Food and Nutrition 36(2): 161-169

TEIXEIRA DA SILVA DE LA SALLES, K., S. M. P. MENEGHETTI, W. FERREIRA DE LA SALLES, M. R. MENEGHETTI, I. C. F. SANTOS, J. P. V. SILVA, S. H. V. CARVALHO \& J. I. SOLETTI, 2010. Characterization of Syagrus coronata (Mart.) Becc. oil and properties of methyl esters for use as biodiesel. Industrial Crops and Products 32(3): 518-521. DOI: <https://doi.org/10.1016/j. indcrop.2010.06.026>.

TELES, C. V., 2014. Caracterização química e avaliação da atividade antioxidante in vitro do extrato rico em polifenóis das folhas de Syzygium cumini (L.) Skeels. Dissertação (Mestrado em Ciências da Saúde) - Universidade Federal do Maranhão, São Luís.
TORRES, E. A. F. S., N. C. CAMPOS, M. DUARTE, M. L. GARBELOTTI, S. T. PHILIPPI \& R. S. M. RODRIGUES, 2000. Composição centesimal e valor calórico de alimentos de origem animal. Ciência e Tecnologia de Alimentos 20(2): 145-150. DOI: <http://dx.doi.org/10.1590/S0101-20612000000200003>.

VILLACHICA, H., J. E. U. CARVALHO, C. H. MULLER, S. C. DIAZ \& M. ALMANZA, 1996. Frutales y hortalizas promisorios de la Amazonía. Tratado de Cooperacion Amazonica, Secretaria Pro-Tempore (TCA-SPT. Publicaciones, 44), Lima.

WANG, L. F., J. Y. CHEN, H. H. XIE, X. R. JU \& R. H. LIU, 2013. Phytochemical profiles and antioxidant activity of adlay varieties. Journal of Agricultural and Food Chemistry 61(21): 5103-5113. DOI: <https://doi.org/10.1021/jf400556s>.

YAMAGUCHI, K. K. L., 2015. Caracterização de substâncias fenólicas de resíduos de frutos amazônicos e avaliação para o uso biotecnológico. Tese (Doutorado em Química) - Universidade Federal do Amazonas, Manaus.

YUYAMA, L. K. O., J. P. L. AGUIAR, D. F. S. SILVA FILHO, K. YUYAMA, M. J. VAREJÃO, D. I. T. FÁVARO, M. B. A. VASCONCELOS, S. A. PIMENTEL \& M. S. F. CARUSO, 2011. Caracterização físico-química do suco de açaí de Euterpe precatória Mart. oriundo de diferentes ecossistemas amazônicos. Acta Amazonica 41(4): 545-552. DOI: <http://dx.doi.org/10.1590/ S0044-59672011000400011>.

ZAMBRANA, N. Y. P., A. BYG, J.-C. SVENNING, M. MORAES, C. GRANDEZ \& H. BALSLEV, 2007. Diversity of palm uses in the western Amazon. Biodiversity and Conservation 16(10): 2771-2787. DOI: <https://doi.org/10.1007/s10531-007-9218-y>.

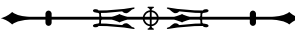


